\title{
Seasonal migration of the snailfish Liparis tanakae and their habitat overlap with o-year-old Japanese flounder Paralichthys olivaceus-ERRATUM
}

TAKESHI TOMIYAMA, MANABU YAMADA AND TETSUYA YOSHIDA ${ }^{1}$

doi: 10.1017/Soo25315413000544, Published by Cambridge University Press, 3 June 2013 (online)

In the abstract of the article, the last sentence was incorrect. The correct sentence is shown below:

'These results suggest that not releasing hatchery-reared Japanese flounder after October can forestall predation by the snailfish.'

\section{REFERENCE}

Tomiyama T., Yamada M. and Yoshida T. (2013) Seasonal migration of the snailfish Liparis tanakae and their habitat overlap with o-year-old Japanese flounder Paralichthys olivaceus. Journal of the Marine Biological Association of the United Kingdom, in press. 